\title{
Behavioral Paradigms in the Short Fiction of Henry James: An Intersubjective Approach ${ }^{1}$
}

\author{
Enikő Bollobás
}

The short fiction of Henry James offers an ideal ground for character studies, in particular the investigation of interactional paradigms, from an intersubjective perspective. Some of James' characters are clearly defined in terms of how they perceive themselves and the others, whether they recognize other perspectives than their own, or not; whether they open onto Others, or not; whether they are touched by Others, or not. Other characters bear gendered marks of language behavior, normative or transgressive styles of speaking. In my study I explore these two major interactional paradigms in James' short fiction, grounding my discussion in intersubjective theory, providing, along the way, an overview of the relevant claims of intersubjective theory that I apply in my interpretation.

I. Intersubjective theory and interactional relations in James's short fiction

The concept of intersubjectivity was introduced in Husserl's Sorbonne lectures (1929), later published as Cartesian Meditations. Here Husserl claims that the recognition of other subjectivities — of the existence and individual aims of Othersprovides the grounds for all ethical relations. "Within the bounds of positivity we say and find it obvious that, in my own experience, I experience not only myself but Others-in the particular form: experiencing someone else" (Cartesian Meditations 48). This ethical relation-that includes both recognition and self-recognition, presence and co-presence-acts as the condition for perceiving the world from the perspective of the Other; in other words, as the condition of objectivity. For objectivity - when I realize that my perspective is one of many, therefore, I hold no privilege on truth-is fundamentally intersubjective. We can only experience the world as an intersubjective medium if we also realize that Others experience it differently, or if we are capable of transgressing the particularity of our perspective. Otherwise we do not perceive the Other as subject but only as object, the object of our perception.

1 Research for this publication was made possible by the National Research, Development, and Innovation Office, Budapest, in support of the Thematic Excellence Program Community Building: Family and Nation, Tradition and Innovation, Eötvös Loránd University, 2020/21. 
In his 1923 essay Ich und Du (English translation, I and Thou, to appear in 1937), Martin Buber describes a "twofold attitude" of man to the world: the I-It and the I-Thou relation; here the I-It relation does not involve "the whole being," but the I-Thou relation does ( $I$ and Thou 3). While the former sees the Other as object, the latter experiences the Other as consciousness and subject. "If I face a human being as my Thou," Buber writes, "he is not a thing among things, and does not consist of things [...] he is Thou and fills the heavens" (8). Buber insists on the reciprocity of this relationship, which corresponds to what intersubjective theory defines as recognition, claiming that the simultaneity of I-affecting-Thou and Thouaffecting-I account for this "primal experience" (21-22) or "relational event" (33). Moreover-and here Buber forecasts a fundamental principle of intersubjective theory-, it is by this recognition of the Other that the subject comes about: "Through the Thou a man becomes $I$ " (28).

Theories of recognition emphasize the intimate connection between recognition and self-recognition, or recognition and self-consciousness. The self cannot recognize itself without recognizing the Other. This is the foundation of all human communication; as Jenny Slatman claims, "I recognize myself, distinguished from that which does not belong to me: and I recognize the Other as a being who, like myself, has a sense of herself and may be concerned for herself ("A Strange Hand" 321-322). Perception, Slatman goes on, is always linked to a particular horizon entailing a particular perspective. But relations and consequently recognition can only come about if the horizons meet: if the participants share a world (329); "one recognizes the Other as someone with whom one shares a meaningful world" (340). Nick Crossley also identifies the recognition of other consciousnesses as the precondition of self-awareness, self-consciousness. Consciousness, he claims, must decenter itself, "identifying and acknowledging its own particularity as a perspective upon the world amongst other perspectives" (17).

James offers diverse explorations of characters who are unable to open to the Other and occupy a shared world with the Other, and who, therefore, are unable to experience the world in its fullness. Indeed, the typical James hero is a voyeur and a scopophiliac, whose gaze is one-directional and static. For example, the narcissistic John Marcher in "The Beast in the Jungle" has only attention to himself, unable to reverse his gaze and see the Other. The painter living in Florence, Theobald from "The Madonna of the Future" sees the beautiful Serafina as the embodiment of the perfect Madonna, whom he could use for his own purpose. Rose Agathe, the eponymous heroine of the short story, is but a hairdresser's tool, an inanimate waxen head serving as the resting place for wigs, who the anonymous narrator falls in love with. In "Glasses," Flora Saunt degrades herself to a mere commodity satisfying the fetishism of the men as she accepts veritable blindness when refusing to wear glasses. 
In the story "Adina," the young woman offers herself to the handsome peasant boy who has been wrongly deprived by Scrope, Adina's former fiancé, of the carved topaz he found in the fields, thus claiming a ridiculously low value of herself in exchange for the stone piece of jewelry dating back to the time of the Emperor Tiberius.

Considering my first example only here, "The Beast in the Jungle," it is fair to claim that, because John Marcher is unable to experience the world by opening up to the Other, he is unable to overcome his inertia. Since, as Brian Massumi puts it, "every perception is a creative activity" (Semblance and Event 27), he is also unable to commit to any creative act. He suffers because he cannot live his life in full; since he has no attention to anyone but himself, he is unable to read himself. May Bartram, on the other hand, is a perceptive woman open to the world, who faithfully stores in her memory all the events relating to the man, capable to call them forth as well. She is a good observer, who can ask pertinent searching questions too. May is a complete human being with the potential to creatively understand the Other; having allowed herself to be touched by the dilemma of Marcher, she opened up to perceiving and experiencing. As one touched by the Other, she manages to gear Marcher to his belated enlightenment. As a person capable of involving the Other into the creative process of perception and cognition, Bartram is both touched and touching, understanding and helping to understand.

Marcher is one of those James heroes who suffer for not knowing who they are. Because they are unable to follow with attention the events around them, they cannot see their own selves either, no matter with what intensity these modern day Narcissuses watch their images in the river. Only very slowly does he learn to see himself from another's perspective; when this happens, it is too late, after May died. His learning curve follows what Merleau-Ponty calls chiasm, the intertwining of perspectives that offers knowledge of oneself.

As soon as I see, it is necessary that the vision (as is so well indicated by the double meaning of the word) be doubled with a complementary vision or with another vision: myself seen from without, such as another would see me, installed in the midst of the visible" ("The Intertwining-The Chiasm" 134)

Desiring knowledge of ourselves, we must learn to be open, the Merleau-Pontyan thesis goes, "to visions other than our own," which then give "the limits of our factual vision" (143). Indeed, this is exactly what happens to Marcher and Bartram: the chiasmatic state of a "reciprocal insertion and intertwining of one in the other" (138) comes about between the man focused on himself and the woman helping the man in his search for his secret, with the "possibility for reversion" (142) taking place as well, as John becomes capable to turn May's perspective into his own. 
Merleau-Ponty insists that such chiasmatic meetings are always grounded in perception. Only perception triggered by the meeting of two sets of eyes, two gazes, can set off a communication process to culminate in knowing: when I think the Other and understand him too. This experience of perception means, he claims, that it brings back the moment when things, truths, and good come to be constituted for us, and that this experience provides us with a logos to be born; for "Perception is a nascent logos" (The Primacy of Perception xv).

By these words, "the primacy of perception," we mean that the experience of perception is our presence at the moment when things, truths, values are constituted for us; that perception is a nascent logos; that it teaches us, outside all dogmatism, the true conditions of objectivity itself; that it summons us to the tasks of knowledge and action. (25)

Judith Butler provides another theoretical link to this problematic. In her recent Senses of the Subject, she devotes three chapters to Merleau-Ponty, pointing out that the French philosopher relies on his Cartesian predecessor of the $17^{\text {th }}-18^{\text {th }}$ century, Nicolas Malebranche, when setting up the three points of the intersubjective process. It is "the primary touch that inaugurates experience" (41), followed by a sense of being touched ("I can feel only what touches me," Malebranche writes [42]), resulting in the sense of the I-the self who feels, knows, and acts. That is, the person reaches the point of subjecthood: becomes a subject capable of feeling, knowing, and acting.

Feeling, knowing, and acting as intersubjective processes are clearly connected through language. The self is forged out of dialogical events channeled by language. The precondition for the subject's opening onto the Other is social dialogue. Marcher's inability to feel is deeply connected with his inability to conduct reciprocal dialogues with Bartram. He needs twenty years to develop in himself a Bakhtinian "responsive attitude," as well as an "actively responsive understanding" (68) of the Other. For twenty years he has no capacity for "co-creation" (172), and only touched by the woman's death does he become capable of "creative understanding" (xiii). During such creative understanding, Bakhtin claims,

it is immensely important for the person who understands to be located outside the object of his or her creative understanding — in time, in space, in culture. For one cannot even really see one's own exterior and comprehend it as a whole, and no mirrors or photographs can help; our real exterior can be seen and understood only by other people, because they are located outside us in space and because they are others. (5) 
Only through the dialogic co-creativity slowly acquired during the twenty years of their conversations will Marcher recognize his cemetery epiphany, when he is touched by an unknown face which he understands to be suffering for the loss of his beloved. The stranger touched by loss becomes the touching, passing on to Marcher the capacity to perceive, to experience, and to live. In other words, Marcher achieves a desired sentience via two intersubjective relations, one with Bartram and another with the stranger, which together, intertwined and chiasmatic, reach the path of what Massumi, relying on Deleuze, calls becoming. Tying relationality to this process, Massumi calls such a process "relational becoming" (Politics of Affect 51), emphasizing the continuous reciprocal events forging the relationship of two people through which knowledge of one is triggered by the perspective of the Other, while also opening a perspective on the world.

James often approaches this problematic from the negative: what happens when the characters are not touched by Others, nor do they experience any forms of relational becoming. The story "In the Cage" presents a telegraphist whose main preoccupation is to put together the details of the lives of the people whose telegraphs she is sending off. No matter how many details she is familiar with, she does not understand her customers' true stories because she is only a voyeur, outside of their intersubjective dialogue. In the absence of reciprocal events, her deciphering proves to be false: the relationship she assumes to be a secret heterosexual romance is presented to the reader as a cover-up rather, and the pain on Captain Everard's face is not from love but from anxiety over being found out and blackmailed. The woman's fictioning of the telegraphs is then prompted by misperception and assumptions pre-existing the texts; her reading is based on her presuppositions concerning the compulsory heterosexuality of love and the assumption that any secret has to somehow relate to illicit heterosexual romance. That is, the absence of reciprocal events - of touching and being touchednecessarily results in the absence of knowledge. And although the reader is not in full possession of knowledge either (James's secrets most often are not revealed), we can suspect at least that the threat of blackmail is somehow connected to the Captain's homosexuality. As such, "In the Cage" is yet another text with which James contributes to the conceptualization of homosexuality going on in the $1890 \mathrm{~s}$ by claiming that understanding requires being touched, while being touched requires a certain intersubjective involvement, the participation in the chiasmic intertwining of perspectives. 


\section{Forms of Gendered Relationality in Language}

Linguistic dialogue plays a crucial role in intersubjective theory, for MerleauPonty in particular. For it is language that forms the "common ground" between the self and the Other in the "experience of dialogue"; it is language that makes up the "common world," where "our perspectives merge into each other" (The Phenomenology of Perception 354). And although we may never be able to fully understand the Other's perspective- "The grief and anger of another have never quite the same significance for him as they have for me. For him these situations are lived through, for me they are displayed" (356) — we can construct a common ground in which to communicate. This linguistic common ground emerges out of a pact, Merleau-Ponty insists, as the "interworld" that is the project of both participating parties (357).

Linguistic common ground serves as the repository of cultural scripts. In his The Presentation of Self in Everyday Life (1956), Erving Goffman writes about "abstract standards" (26) or "abstract stereotyped expectations" (27) that the individual learns so that he or she would know what "officially accredited values of the society" to appropriate during the social performances or presentations of the self (35). While Goffman defines the self as the "product of a scene that comes off [...], as a performed character" (252) or a "dramatic effect" (253), he also allows for a discursive common ground collecting the social scripts that regulate the dramatic staging of the self.

Nancy Chodorow and Jessica Benjamin offer a different perspective on relational events. Writing about "the relational construction of the self" (Chodorow 149), Chodorow ties the "search for meaningful subjectivity" (145) to the topic of intersubjectivity. Refuting the Freudian ideal of individuality defined by separation — an ideal tailored exclusively to male autonomy and individualityChodorow emphasizes the conceptualization of "the self as inexorably social and intrinsically connected" (158). While Freud's model excludes the role of others in the construction of the self, object-relations theory "directs attention to the interrelations of individuality and collectivity or community" (152), and, as a consequence, to the role mutual engagements play in the production of the self. Benjamin also emphasizes that the traditional psychoanalytic model, valorizing separation and differentiation, is helpful in interpreting relationships of domination only, where the separating party realizes his domination over the person he separated from. "The problem of domination begins with the denial of dependency" ("Master and Slave" 283), she writes. This concept of the subject shows a fundamental difference from that of critical feminist psychoanalytical theory, which posits a concept of individualism that balances separation and connectedness, agency, and 
relatedness ("A Desire of Ones's Own" 82). Benjamin insists that the recognition of female desire- "that one is a subject of desire, an agent who can will things and make them happen" (87) — serves as the precondition of female subjectivity. For the intersubjective mode, Benjamin asserts, "assumes the paradox that in being with the Other, I may experience the most profound sense of self" (92). Breaking with "the logic of only one subject" (Shadow of the Other 82), Benjamin's paradigm allows for symmetrical relations between two subjects. According to Benjamin's "intersubjective view," "the individual grows in and through the relationship to other subjects"; for "the Other whom the self meets is also a self, a subject in his or her own right" (Bonds of Love 19-20).

Linguistic dialogue serves as an important pillar in Butler's intersubjective theory. In her Adorno lectures, given in 2003 and published in 2006 as Giving an Account of Oneself, she takes Nietzsche's starting point claiming, "I begin my story of myself only in the face of a 'you' who asks me to give an account" (11). Butler connects linguistic context, narrativity, and dialogical relation with the recognition of the Other. Here the illocutionary act of performing the self and the perlocutionary act of persuading the Other meet as they produce an intersubjective relation together. Reinforcing the intersubjective claim concerning the linguistic common ground, Butler also emphasizes that the recognition of the Other and being recognized by the Other can only take place in language (28). For it is language that makes possible narrative recognition and self-narration conducted in order to achieve this recognition; this happens within a linguistic-dialogical situation, where not only is the Other, the addressee of self-narration, present, but also the possibility of persuading the Other. Our narrative self is produced as we talk to someone; the self is born out of a web of relations, when one body talks to another. "My efforts to give an account of myself founder in part because I address my account, and in addressing my account I am exposed to you" (38). Subjectivity, then, is always relational: "the only way to know oneself is through a mediation that takes place outside of oneself" (28). Recognition and self-recognition are, in short, linguistic (or narrative) acts. As such, Butler's concept of intersubjectivity accommodates discursivity and narrativity, the self/Other communicative situation, and the idea of mutual recognition.

James was acutely interested in gendered forms of relationality and the ways language frames gender positions in intersubjective relations. Throughout his career he was preoccupied with the characteristic features of female speech, the significance of silence surrounding women, as well as the subversive act of a woman coming to speak. His critics seem to be in agreement on the peculiar features of the way James's characters speak. Among these, Ralf Norrman discusses referential uncertainty or ambiguity, especially the "confusion in pronominal reference" 
leaving open the question of "who is who" (1); intersentence links suggesting hesitation and the understanding that nothing is ever final; as well as "changes in position" (3), also suggesting insecurity and instability. Although Norrman does not interpret these features as gendered, subsequent research in female languagethat of Robin Lakoff, Carol Gilligan, Deborah Cameron, and Pierre Bourdieu, among others-clearly assigns these marks to women. Studying gendered linguistic norms, Lakoff concludes that language, including its most concrete syntactic and lexical structures, displays marks of power or powerlessness; "language use can tell us about the nature and extent of any inequity" (39). Gilligan claims that patriarchy demands a very specific language use of women; as the manifestation of such social scripts as empathy and intersubjectivity, this voice will be softer and more insecure than that of men, reflecting "the limits of autonomy and control" (172). Cameron describes the "weak, trivial, and deferential style" of women as deriving from their "training in how to be subordinate" (23), while Bourdieu insists on a symbolic relation between language on the one hand and wealth and power on the Other. As he claims, "utterances are not only [...] signs to be understood and deciphered, they are also signs of wealth, intended to be evaluated and appreciated, and signs of authority, intended to be believed and obeyed" (67). And since patriarchy forbids autonomy and self-confidence for women, including female voice, it is no wonder that hesitancy, uncertainty, insecurity, indecision, and vacillation are understood as marks of women's language.

James's short piece entitled "The Story in It" offers an intriguing staging of the linguistic codes of gender. The speech of the two women protagonists, Mrs. Dyott and Maud Blessingbourne is characterized by exactly those features described by Norrman, namely, referential uncertainty or ambiguity, intersentence links, and a general sense of hesitancy manifest in a linguistic yielding to the male speaker, Colonel Voyt. As Donatella Izzo observes, "Maud uses interrogative, tentative, and reticent tones, and Mrs. Dyott only speaks to echo someone else's words" (217). As so many other James pieces, this story is characterized by "the Jamesian poetics of the narratibility of a nonstory," as Izzo puts it, (216), suggesting, in other words, that, apart from the power game of appropriating or not appropriating language, nothing actually happens. Their three-way dialogue hides an intricate triangular desire that encompasses two desiring women and one man, the common object of their longing. How very different this triangle is from the dominant intersubjective model captured by Claude Lévi-Strauss, René Girard, Eve Kosofsky Sedgwick, and Mary Jacobus, in which woman acts as the mediator and vehicle between the homosocial desires of men. Not only are the gender positions reversed in the James story, but the direction of desire too: it is not the man who mediates between the desires of the women, nor do the women desire each other. Moreover, the women 
seem to be unable to give voice to their desires. In other words, although women start to own desire, their social subjection continues to gain expression in female silence and linguistic insecurity.

Female silence gets foregrounded in several James texts problematizing language and in particular the absence of speech as marks of one-directional and, consequently, failed attempts at intersubjective relations, as well as the symbolic linguistic manifestations of power structure. Intersubjectivity, whether successful or failed, is regularly treated in terms of gender binaries, assigning first-person speech to men and hesitancy and silence to women.

"The Beast in the Jungle" offers one of the most memorable cases of female silence. Throughout this story that I have already discussed earlier from a different perspective, the woman does nothing else but listen to the man. John Marcher, the protagonist portrayed as an extreme narcissist speaks to his listener for twenty years about his grand secret, hoping that the woman will help him uncover its content (which he himself does not know). The secret never revealing itself is the overriding theme of the story, the same as the theme of the decades-long asymmetrical encounter, assigning to woman the patriarchal role of the patient listener and to the man the no less patriarchal role of the self-centered speaker. While the subject of the story as well as their dialogue manqué refers to the secret homosexual desire of Marcher, the behavior of the woman participating in this search points at another, no less silenced secret, the meaning of female listening and female silence. In other words, James presents the mysterious silence surrounding the taboo topic of homosexuality in such a way that he discusses at the same time another taboo topic relating to female submission coded in gendered discourse.

In some other stories, however, James seems to revise this binary gender script. For beside presenting characters who fully appropriate the linguistic codes of femininity, the author introduces women who demand a voice of their own in a subversive act that is allowed at times but forbidden at others. This is a radical innovation indeed, explicitly countering the traditional patriarchal interpretation of the relationship between gender and language.

The punishment of the woman who speaks provides the theme of the story "The Visits," in which the young Louisa Chantry must die after she repeatedly proclaims her love for Jack Brandon, thereby transgressing the normative Victorian gender script concerning the unsayability of female desire. What complicates her crime is the fact that her admission comes at her own initiative (she speaks "first"), and not as a response to the man's confession. As such, female autonomy does not only violate Victorian etiquette but the whole Western patriarchal set of norms concerning the demand that woman keep quiet and wait to be addressed by the man. 
Side by side with woman respecting patriarchy's gender scripts James presents several woman characters who proclaim themselves autonomous subjects and even agents, having appropriated agency by some form of Foucauldian assujettissement: they look, speak, and act. This is indeed a most revolutionary feature of James's writing, assigning individual personhood through relationality to women; as Joyce Warren points out, "What is revolutionary about Henry James's The Portrait of a Lady (1880) is his depiction of the American individualist as a woman" (231), that is, his recognition of "the personhood of women" (239).

Agency appropriated by woman through language is problematized in "Julia Bride." The beautiful young woman gains a bad reputation in society because her mother had been married and divorced several times; moreover, her own engagements were broken several times. In order to save her reputation, Julia devises an elaborate performance involving friends, the mother's former husbands and her own former fiancés who are to attest to the fact that neither of the women are to blame for the liaisons gone wrong. In this extraordinary story we hear the thoughts of the woman as the speaker of third-person internal monologues reflecting the thinking mind of a person learning to claim agency to herself. The free indirect discourse reveals a woman who refuses victimhood; she does this by adopting a speech style that goes counter to all norms, approaching the speaking voice usually associated with men.

The female protagonist of "Georgina's Reasons" also belongs among James's women who speak (and speak a lot). Georgina is a sexual creature driven by her desires; she is an autonomous and assertive young woman who actually commits the crime of bigamy by first marrying the navy officer Raymond Benyon and later a wealthy businessman. She cleverly evades getting into trouble because the first husband is tied by the prenuptial promise to keep silent about the marriage. Such silencing of the man reverses the traditional gender division assigned to man as speaking agency: while Georgina speaks incessantly, repeatedly explaining, in a most self-conscious manner, the reasons behind her acts, the man is sentenced to silence. Georgina's transgression is twofold: not only does she appropriate language from the man, she does this in order to satisfy her sexual desire, by violating the laws of patriarchy with both acts.

Similarly active and assertive is the heroine of the story "Mora Montravers," who decides to marry, albeit as a formality, Walter Puddick, the genius artist with whom she had studied painting. With her marriage scheme she aims to secure the annuity from her aunt and thereby to realize her artistic aspirations. Mora is a thinking woman with her own voice: a heroine, as Izzo points out, "who knows and who wills, and she is a winner" (258). That is, countering the patriarchal script and appropriating language from men, she forges her own agency. From an 
intersubjective perspective one can posit that the antipatriarchal Mora conducts a dialogue with the scripts of patriarchy when reversing the roles assigned to men and women; not only does the woman come to speech here but assigns the female position of silence to the man.

James is known to have no final word on human relations in his fiction, but to constantly reevaluate the interactions of his characters. As he wrote to Mrs. F. H. Hill, on March 21, 1879, "Nothing is my last word on anything-I am interminably super-subtle and analytic - and with the blessing of heaven, I shall live to make all sorts of representations of all sorts of things" (Selected Letters 161). Yet "Mora Montravers," the last story James wrote, does give his "last word" of sorts on a young woman with a mind of her own. As the culminating point in the long line of stories depicting women trying to break free, "Mora Montravers" is, as Izzo puts it, "the final seal to his representation of the feminine," casting "a retrospective light over the long road traveled that far" (258), while also offering, through a deep analysis of intersubjective relations, the ultimate dream of subjectivation and agency.

\section{WORKS CITED}

Bakhtin, Mikhail. Speech Genres and Other Late Essays. Trans. Vern W. McGee. Ed. Caryl Emerson, Michael Holquist. Austin: U of Texas P, 1986.

Benjamin, Jessica. Shadow of the Other-Intersubjectivity and Gender in Psychoanalysis. New York: Routledge, 1988.

Benjamin, Jessica. The Bonds of Love-Psychoanalysis, Feminism, and the Problem of Domination. New York: Pantheon Books, 1988.

Benjamin, Jessica. "Master and Slave_-The Fantasy of Erotic Domination." Powers of Desire. The Politics of Sexuality. Ed. Ann Snitow, Christine Stansell-Sharon Thompson. New York: Monthly Review P, 1983. 280-99.

Benjamin, Jessica. "A Desire of One's Own. Psychoanalytic Feminism and Intersubjective Space." Feminist Studies, Critical Studies. Ed. Teresa de Lauretis. Bloomington: Indiana UP, 1986. 78-101.

https://doi.org/10.1007/978-1-349-18997-7_6

Bourdieu, Pierre. Language and Symbolic Power. Ed. John B, Thompson. Trans. Gino Raymond, Matthew Adamson. Cambridge: Harvard UP, 1991. 
Buber, Martin. I and Thou. Trans. Ronald Gregor Smith. New York: Scribner, 1958.

Butler, Judith. Giving an Account of Oneself. New York: Fordham UP, 2005. https://doi.org/10.5422/fso/9780823225033.001.0001

Butler, Judith. Senses of the Subject. New York, Fordham UP, 2015. https://doi.org/10.1515/9780823264698

Cameron Deborah, ed., The Feminist Critique of Language - A Reader. London: Routledge, 1990.

Chodorow, Nancy J. Feminism and Psychoanalytic Theory. New Haven: Yale UP, 1989.

Crossley, Nick. Intersubjectivity —The Fabric of Social Becoming. London: Sage Publications, 1996.

Gilligan Carol. In a Different Voice: Psychological Theory and Women's Development. Cambridge: Harvard UP, 1982.

Girard, René. Deceit, Desire, and the Novel, Self and Other in Literary Structure. Trans. Yvonne Freccero. Baltimore: Johns Hopkins UP, 1972.

Goffman, Erving. The Presentation of Self in Everyday Life. New York, Doubleday, 1959.

Husserl, Edmund. Cartesian Meditations. Trans. Dorion Cairns. The Hague: Martinus Nijhoff, 1982.

Izzo, Donatella. Portraying the Lady: Technologies of Gender in the Short Stories of Henry James. Lincoln: U of Nebraska P, 2001.

Jacobus, Mary. Reading Woman: Essays in Feminist Criticism. New York. Columbia UP, 1986.

https://doi.org/10.7312/jaco 92530

James, Henry. Selected Letters. Ed. Leon Edel. Boston: Harvard UP, 1987.

Lakoff, Robin. Language and Woman's Place: Text and Commentaries. Ed. Mary Bucholtz. New York: Harper, 2004.

Lévi-Strauss, Claude. The Elementary Structures of Kinship. Trans. John Richard von Sturmer, James Harle Bell, Rodney Needham. Boston: Beacon P, 1969. 
Massumi, Brian. Politics of Affect. Cambridge: Polity, 2015.

Massumi, Brian. Semblance and Event: Activist Philosophy and the Occurrent Arts. Cambridge: The MIT P, 2013.

Merleau-Ponty, Maurice. The Phenomenology of Perception. Trans. Colin Smith. London: Routledge, 1962/1992.

Merleau-Ponty, Maurice. "The Intertwining-The Chiasm." The Visible and the Invisible. Trans. Alphonso Lingis. Evanston: Northwestern UP, 1968. 130-155.

Merleau-Ponty, Maurice. The Primacy of Perception and Other Essays on the Phenomenological Psychology, the Philosophy of Art, History and Politics. Trans. James M. Edie. Evanston: Northwestern UP, 1964.

Norrman, Ralf. The Insecure World of Henry James's Fiction: Intensity and Ambiguity. London: Macmillan P, 1982. https://doi.org/10.1007/978-1-349-16824-8

Sedgwick, Eve Kosofsky. Between Men, English Literature and Male Homosocial Desire. New York. Columbia UP, 1985. https://doi.org/10.7312/sedg90478

Slatman, Jenny. "A Strange Hand: On Self-Recognition and Recognition of Another." Phenomenology and the Cognitive Sciences 8 (2009). 321-342. https://doi.org/10.1007/s11097-009-9127-5

Warren, Joyce W. The American Narcissus: Individualism and Women in NineteenthCentury American Fiction. New Brunswick: Rutgers UP, 1989. 